\title{
Pengaruh Pelayanan terhadap Kepuasan Pelanggan pada Angkringan Abah Agus Karawang
}

\author{
Moch Agus Ariffianto, ${ }^{1}$ Rian Permana Suryadipraja,, 2 Rohma Septiawati, ${ }^{3}$ Arman \\ Paramansyah $^{4}$
}

STIT Rakeyan Santang Karawang, ${ }^{1,2}$ Universitas Buana Perjuangan, ${ }^{3}$ IAIN Laa Roiba Bogor ${ }^{4}$

1agusrakeyansantang@ac.id,2rianrakeyansantang@ac.id,,3rohmaseptiawati@ubpkarawang. ac.id, ${ }^{4}$ paramansyah.aba@gmail.com

\begin{tabular}{l}
\hline Informasi artikel \\
\hline Kata kunci: \\
Pelayanan \\
Kepuasan Pelanggan \\
UMKM Angkringan
\end{tabular}

Keywords:

Service

Customer Satisfaction

UMKM Angkingan

\begin{abstract}
ABSTRAK
Penelitian ini akan membahas mengenai proses pelayanan Angkringan terbadap Kepuasan para pelanggan. Sejalan dengan masalab tersebutpenelitian ini dilaksa nakan dengan menggunakan Penelitian Kuantitatif dengan metode deskriptif analisis, yaitu penelitian dengan memusatkan perbatian pada aspek-aspek tertentu dan menunjukan adanya bubungan antara berbagai variable, kemudian mengadakan deskripsi untuk. memberikan gambaran yang jelas. Berdasarkan hasil analisapada Angkringan Abah Agus Karawang, maka dapat disimpulkan nilai Koefisien korelasi antara kedua variabel $X$ dan variabel $Y$ dimana dibasilkan nilai $r=0,51$ terdapat bubungan yang cukup kuat, dan didasarkan dari Koefisien regresi $Y=31,16+7,5 X$, artinyajike a nilai $X$ bertambah maka nilai $Y$ akan semakin besar. Hal ini telab dibuktikan melalui uji $\mathrm{F}$, dimana hasil uji $\mathrm{F}$ memperlihatkan bahwa F-bitung $>$ F-tabel yang dalam penelitian ini telah terbukti dan dapat diterima. Dan kepuasan pelangsan, berpengarub positif dan signifikan berarti kedua variable dalam penelitian ini tidak adanya variabel yang lebih dominan sehingga dinyatakan tidak terbukti dan tidak dapat diterima. Berdasarkan temuan tersebut maka Angkringan Abah Agus karawang di sarankan perlunya peningkatan mutu pelayanan yang diberikan sebagai rangsangan untuk meningkatkan kepuasan pelanggan angkringan dan untuk mendapatkan kepuasan pelanggan yang dibarapkan juga Perlu adanya proses penilaian yang berkala atas pelayanan yang diberikan sebagai tolak ukur kepuasan yang tepat bagi pelanggan.
\end{abstract}

\section{ABSTRACT}

The Effect of Service on Customer Satisfaction at Abah Agus Karawang. This study will discuss about the Angkringan service process on customer satisfaction. In line with this problem, this research was carried out using quantitative research with descriptive analysis methods, namely research by focusing on certain aspects and showing the relationship between various variables, then conducting descriptions to provide a clearpicture. Based on the results of the analysis on Angkringan Abah Agus Karawang, it can be concluded that the value of the correlation coefficient between the two variables $X$ and variable $Y$ where the resulting value $r=0.51$ has a strong enough relationship, and is based on the regression coefficient $Y=31.16+7.5 X$, meaning that if the $X$ value increases, the $Y$ value will be even greater. This has been proven through the F test, where the F test results show that the F-count $>$ F-table which in this study has been proven and acceptable. And customer satisfaction, has a positive and significant effect, it means that the two variables in this study are not the more dominant variables so that they are declared unproven and unacceptable. Based on these findings, Angkeringan Abab Agus Karawang suggested the need to improve the quality of services provided as a stimulus to increase customer satisfaction of angkringan and to get the expected customer satisfaction. There is also a need for a periodic assessment process for the services provided as a measure of appropriate satisfaction for customers.

Copyright (C) 2021 (M.Aus Arifianto, dkk). DOI: https://doi.org/10.52593/mtq.02.2.05 Naskah diterima: 31 Mei 2021, direvisi: 27 Juli 2021, disetujui: 30 Juli 2021 
Jurnal Muttaqien, Vol. 2. No. 2 Juli 2021, 155-175

\section{A. Pendahuluan}

Pelayanan merupakan suatu fenomena yang unik, sebab dimensi dan indikatornya diantara orang-orang yang terlihat dalam pelayanan. Dengan demikian, yang dimaksud dengan pelayanan adalah yang menunjukkan pada tingkat kesempurnaannya dalam menimbulkan rasa puas pada diri pada setiap pelanggannya. Menurut Napitupulu (2007:164), Pelayanan adalah serangkaian kegiatan suatu proses pemenuhan kebutuhan orang lain secara lebih memuaskan berupa produk jasa dengan sejumlah ciri seperti tidak terwujud, cepat hilang, lebih dapat dirasakan daripada memilki, dan pelanggan lebih dapat berpartisispasi aktif dalam proses mengkonsumsi jasa tersebut.

Kepuasan dapat diartikan sebagai pemenuhan sesuatu atau membuat sesuatu memadai setelah membandingkan persepsi kinerja atau hasil produk dengan harapanharapannya. Dari pengertian diatas bahwa peran pelayanan merupakan hal yang sangat penting dan sangat berpengaruh, tanpa adanya pelayanan yang tepat maka produk akan kurang diminati oleh pelanggan. Salah satu usaha yang sedang booming saat ini adalah bisnis angkringan, yang mulai banyak bertebaran di karawang dan kota-kota lainnya. Di berbagai penjuru ibu kota beberapa beberapa tahun ini bermunculan dibanyak kawasan dimana cukup mudah menemukan angkringan yang biasanya mulai buka sore hari sampai menjelang pagi. Dari angkringan yang dalam bentuk gerobak yang menyediakan macammacam jenis kopi sampai angkringan semi permanen tempatnya yang menawarkan kopi enak yang kini tidak hanya kafe mentereng yang bisa menyuguhkan kopi enak tersebut.

Angkringan Abah Agus di karawang dengan tempat semi permanen memang menjadi tempat rujukan bagi anak-anak yang sangat suka begadang sampai komunitas pengendara sepeda motor. Sepintas bila dilihat memang semakin malam semakin ramai sepeda motor yang parkir dari kalangan karyawan yang berkunjung sepulang bekerja, mereka datang secara kelompok atau sendiri-sendiri. Mereka tampak menikmati macammacam kopi dari yang sachet sampai jenis kopi yang varian Nusantara dan beberapa makanan sajian angkringan. Bahkan kalangan ini sepertinya duduk sambil beraktivitas ala kantor menggunakan laptop sambil memakai fasilitas wifi yang telah disediakan secara gratis di angkringan tersebut, sehingga seolah-olah mereka menemukan semacam outside office yang nyaman.

Pepatah mengatakan "hidup dikota tanpa bersiasat, dapat tersesat", itulah yang dianut pemilik angkringan Abah Agus, dengan menempati lokasi angkringan semi permanen, 
angkingan ini mampu menyuguhkan atmosfer damai dan nyaman. Angkringan Abah Agus termasuk katagori ramai, hal ini berbeda dengan pemandangan angkringan lainnya yang sepi pengunjung, Angkringan Abah Agus tidak pernah sepi pengunjung walaupun jenis usaha sama, hanya berbeda nama, jenis sajian yang disuguhkan juga tidak berbeda, tetapi mungkin senyum, sapa, dan keinginan pramusaji untuk memberikan pelayanan sigap sehingga kebutuhan pelanggan terpenuhi dengan cepat, hal ini pasti dapat memberikan kesan yang berbeda kepada setiap pelanggan dan akhirnya pelanggan seolah terbiasa untuk mampir membeli di angkringan abah agus ini. Angkringan abah agus ini berusaha membuat pelanggan nyaman karena pemiliknya ramah, harganya juga sangat ramah dikantong.

Peneliti sering berbicara dengan Pemilik Angkringan Abah Agus yang beralamat di Kp Guro II Karawang Wetan, namun ternyata sang pemilik masih menginginkan bagaimana caranya agar angkringannya dapat seramai seperti kafe-kafe besar diluar sana. Peneliti menilai wajar apabila makin ramai pasti keuntungan semakin meningkat, ada sesuatu yang kurang dalam usaha Angkringan Abah Agus ini, sehingga belum memberikan rasa kepuasan pelanggan secara optimal yang mampu memberikan daya tarik tersendiri.

\section{B. Teori / Konsep}

\section{Pengertian Pelayanan}

Menurut Sampara dalam Sinambela (2011:5) mengatakan: Pelayanan adalah suatu kegiatan atau urutan kegiatan yang terjadi dalam interaksi langsung antar seseorang dengan orang lain atau mesin secara fisik, dan menyediakan kepuasan pelanggan. Jadi pelayanan yaitu interaksi secara langsung antar seseorang dengan orang lain dan pelayanan juga merupakan penyediaan kepuasan bagi pelanggan.

Menurut Moenir (2001:47) mengatakan: Pelayanan umum yang didambakan adalah kemudahan dalam mengurus kepentingan mendapatkan pelayanan yang wajar, perilaku yang sama tanpa pilih kasih dan perlakuan yang jujur dan terus terang. Disamping itu, ia juga menambahkan bahwa kelancaran layanan hak-hak tergantung pada kesediaan para petugas terhadap kewajiban yang dibebankan, sistem, prosedur, dan metode yang memadai, pengorganisasian tugas pelayanan yang tuntas, pendapatan petugas atau pegawai yang cukup untuk kebutuhan hidupnya, kemampuan atau keterampilan pegawai, dan sarana kerja yang memadai. Jadi Pelayanan mempermudah mengurus kepentingan agar memberikan 
Jurnal Muttaqien, Vol. 2. No. 2 Juli 2021, 155-175

pelayanan yang wajar, dan menyediakan pelayanan yang memadai dari kesediaan petugas dan keterampilan pegawai.

\section{Pengertian Kepuasaan}

Menurut Kotler (1988) mengatakan: Kepuasan adalah tingkat kepuasan seseorang setelah membandingkan kinerja atau hasil yang dirasakan dibandingkan dengan harapannya. Jadi kepuasan atau ketidakpuasan adalah kesimpulan dari interaksi antara harapan dan pengalaman sesudah memakai jasa atau pelayanan yang diberikan.

\section{Pengertian Kepuasaan Pelanggan}

Menurut Zeithaml dan Bitner (2000:75) mengatakan: Definisi kepuasan adalah Respon atau tanggapan konsumen mengenai pemenuhan kebutuhan. Kepuasan merupakan penilaian mengenai ciri atau keistimewaan produk atau jasa, atau produk itu sendiri, yang menyediakan tingkat kesenangan konsumen berkaitan dengan pemenuhan kebutuhan konsumsi pelanggan.

Kepuasan konsumen adalah tingkat perasaan konsumen setelah membandingkan antara apa yang dia terima dan harapannya (Umar, 2005:65). Seorang pelanggan, jika merasa puas dengan nilai yang diberikan oleh produk atau jasa, sangat besar kemungkinannya menjadi pelanggan dalam waktu yang lama.

Sementara menurut Zeithaml dan Bitner (2012), lima hal yang mempengaruhi kepuasan pelanggan, yaitu:

1. Productand Service Features (Fitur produk dan pelayanan)

Fitur dari produk dan jasa yang disampaikan kepada pelanggan menjadi aspek penting dalam menentukan persepsi atau penilaian pelanggan dalam menciptakan kepuasan pelanggan itu sendiri.

2. Consumer Emotion (Emosi konsumen)

Emosi yang dimaksud adalah suasana hati. Suasana hati pelanggan yang sedang gembira cenderung akan berpengaruh terhadap respon atau persepsi yang positif terhadap produk atau jasa yang diberikan, sebaliknya suasana hati atau emosi pelanggan yang buruk, maka emosi tersebut akan membawa respon atau persepsi yang negatif terhadap produk atau jasa yang diberikan.

3. Attribution for Service Successor Failure (Atribusi pelayanan yang gagal)

Pelayanan yang diberikan kepada pelanggan dapat menjadi lebih buruk atau lebih baik dari yang diharapkan. Apabila pelayanan yang diberikan sesuai atau bahkan melampaui 
harapan pelanggan, maka dapat dikatakan pelayanan tersebut adalah pelayanan yang sukses, sebaliknya apabila pelayanan yang diberikan tidak sesuai dengan harapan pelanggan, maka dapat dikatakan bahwa proses pelayanan tersebut mengalami kegagalan. Dalam kesuksesan dan kegagalan penyampaian proses pelayanan tersebut, pelanggan akan mencari tahu penyebab dari kesuksesan atau kegagalan penyampaian pelayanan. Kegiatan pelanggan dalam mencari tahu penyebab suatu kesuksesan dan/atau kegagalan inilah yang dapat mempengaruhi tingkat kepuasan pelanggan terhadap suatu barang dan jasa.

4. Perception of Equity and Fairness (Persepsi persamaan dan keadilan)

Pelanggan yang membeli suatu produk atau jasa akan cenderung bertanya pada diri mereka sendiri: “Apakah saya telah dilayani secara adil dibandingkan dengan pelanggan yang lain? Apakah pelanggan lain mendapatkan harga yang lebih murah, atau pelayanan yang lebih baik? Apakah saya membayar harga yang layak untuk sebuah produk atau layanan jasa yang saya dapatkan?" Pemikiran pelanggan mengenai persamaan dan keadilan ini dapat mengubah persepsi pelanggan dalam tingkat kepuasannya terhadap suatu produk atau jasa.

5. Other Cunsomer, Family Member, and Coworkers (Pelanggan lain, anggota keluarga dan rekan kerja)

Kepuasan pelanggan terhadap suatu produk atau jasa dipengaruhi oleh ekspresi orang lain yang menceritakan kembali bagaimana mereka merasa puas atau tidak puas terhadap produk atau jasa tersebut.

\section{Metode Penelitian}

Jenis penelitian ini dilaksanakan dengan menggunakan Kuantitatif dengan menggunakan metode deskriptif analisis, yaitu penelitian dengan memusatkan perhatian pada aspek-aspek tertentu dan menunjukan adanya hubungan antara berbagai variable, kemudian mengadakan deskripsi untuk memberikan gambaran yang jelas. Pemilihan jenis penelitian kuantitatif deskiptif dirasa cocok dengan tujuan penelitian pada Angkringan Abah Agus Karawang. 
Kriteria penilaian jawaban pertanyaan

\begin{tabular}{|c|c|c|}
\hline Range skor & Jumlah nilai jawaban & Kriteria penilaian \\
\hline $4,01-5$ & $121-150$ & Sangat baik \\
\hline $3,01-4$ & $91-120$ & Baik \\
\hline $2,01-3$ & $61-90$ & Cukup baik \\
\hline $1,01-2$ & $31-60$ & Tidak baik \\
\hline 1 & 30 & Sangat tidak baik \\
\hline
\end{tabular}

\section{Hasil Penelitian dan Pembahasan}

\section{Gambaran Umum Usaha}

Angkringan Abah Agus Karawang berdiri pada tahun 2018, yakni diresmikan dibukanya angkringan ini di tanggal 17 Agustus 2018. Mengapa harus di tanggal 17 pemilik sengaja meresmikan membuka angkringan ini di tanggal 17 karena di tanggal 17 ini bertepatan dengan tanggal kemerdekaan Indonesia. Nama Angkringan Abah Agus di ambil dari nama pemilik yang asli daerah supaya selalu dekat pelanggan dengan suasana budaya sunda yang memang sudah dikenal bahwa budaya sunda adalah orang memiliki ciri khas tertentu yang membedakannya dari kebudayaan-kebudayaan lain. Secara umum masyarakat Jawa Barat atau Tatar sunda, sering dikenal dengan masyarakat religius, Kecenderungan ini tampak sebagaimana dalam pameo "silih asih, silih asah dan silih asuh, saling mengasihi, saling mempertajam diri dan saling malindungi.

Selain itu Sunda juga memiliki sejumlah budaya lain yang khas seperti kesopanan, rendah hati terhadap sesama, kepada yang lebih tua dan menyayangi kepada yang lebih kecil.

Angkringan ini bernuansa dari perpaduan Tradisional dan Modern, di angkringan ini juga menyediakan makanan dan minuman dari mulai khas Tradisional hingga Modern. Namun angkringan ini tetap mudah di kenali karena masih tetap dengan ciri khasnya yaitu gerobak kayu. Nuansa dari Angkringan Abah Agus ini juga masih sangat tradisional yakni dengan adanya bingkai-bingkai bergambar sejarah yang di paparkan di dinding dan lampu remang-remangnya yang menjadi ciri khas angkringan. Angkringan Abah Agus ini memadukan dengan nuansa yang modern seperti adanya musik untuk menciptakan suasana yang lebih nyaman dan juga adanya akses Wifi untuk menunjang para pengunjung untuk bisa mengerjakan tugas kantor (bagi pekerja) dan tugas kampus (bagi mahasiswa). 


\section{E. Analisa data Penelitian}

Seperti telah disebutkan diatas data penelitian ini menyangkut dua variable yaitu terdiri dari Pelayanan sebagai variable bebas (x) dan Kepuasan Pelanggan sebagai variable terikat (y). Tujuan juga meneliti dan sekaligus membuktikan apakah pelayanan yang dijalankan antara pemilik dan pelanggan atau pelayanan antar sesama pelanggan dapat membawa pengaruh positif terhadap kepuasan pelanggan di Angkringan Abah Agus Karawang. Jumlah pelanggan yang ada dilingkungan Angkringan Abah Agus sebagai subjek penelitian berpopulasi 30 orang pelanggan. Kemudian peneliti melaksanakan pengumpulan data dengan cara menyebarkan sebanyak 30 set angket/kuesioner terhadap 30 orang pelanggan/responden penelitian tersebut. Kuesioner tersebut terdiri atas 2 (dua) bagian yaitu kuesioner tentang pelayanan dan kuesioner tentang kepuasan pelanggan.

\section{Tabulasi Jawaban Variabel Pelayanan (X) dengan skla Liker}

1. Pelayanan yang baik dapat mempengaruhi kepuasan

\begin{tabular}{|c|c|c|c|c|c|}
\hline \multicolumn{7}{|c|}{ PELAYANAN 1 } \\
\hline \multirow{2}{*}{} & Frequency & Percent & Valid Percent & $\begin{array}{c}\text { Cumulative } \\
\text { Percent }\end{array}$ \\
\hline \multirow{4}{*}{ Valid } & 3 & 4 & 13,3 & 13,3 & 13,3 \\
\cline { 2 - 6 } & 4 & 12 & 40,0 & 40,0 & 53,3 \\
\cline { 2 - 6 } & 5 & 14 & 46,7 & 46,7 & 100,0 \\
\cline { 2 - 6 } & Total & 30 & 100,0 & 100,0 & \\
\hline
\end{tabular}

Dengan pertanyaan nomor 1 ini, bila nilai jawabannya dijumlahkan yaitu $(14 \mathrm{x} 5)+(12 \times 4)$ + (4 x 3) maka akan diperoleh nilai sebesar 130 Angka tersebut bila dibagi dengan jumlah responden sebanyak 30 orang akan menghasilkan nilai 130: $30=4,33$ Kemudian bila dibandingkan dengan kriteria penilaian, maka 4,33 termasuk kedalam kriteria sangat baik.

\section{Membentuk budaya perusahaan secara internal dengan baik pelanggan akan} merasa puas

\begin{tabular}{|c|c|c|c|c|c|}
\hline \multicolumn{7}{|c|}{ PELAYANAN 2 } \\
\hline \multirow{2}{*}{} & \multirow{2}{*}{ Frequency } & Percent & Valid Percent & $\begin{array}{c}\text { Cumulative } \\
\text { Percent }\end{array}$ \\
\hline \multirow{4}{*}{ Valid } & 3 & 7 & 23,3 & 23,3 & 23,3 \\
\cline { 2 - 6 } & 4 & 8 & 26,7 & 26,7 & 50,0 \\
\cline { 2 - 6 } & 5 & 15 & 50,0 & 50,0 & 100,0 \\
\cline { 2 - 6 } & Total & 30 & 100,0 & 100,0 & \\
\hline
\end{tabular}


Jurnal Muttaqien, Vol. 2. No. 2 Juli 2021, 155-175

Dengan pertanyaan nomor 2 ini, bila nilai jawabannya dijumlahkan yaitu $(15 \times 5)+(8 \times 4)$ + (7 x 3) maka akan diperoleh nilai sebesar 128 Angka tersebut bila dibagi dengan jumlah responden sebanyak 30 orang akan menghasilkan nilai 128: $30=4,26$ Kemudian bila dibandingkan dengan kriteria penilaian, maka 4,26 termasuk kedalam kriteria sangat baik.

3. Mendapatkan perlakuan yang sama tanpa pilih kasih, perlakuan yang jujur dan terus terang akan menciptakannya kepuasan terhadap pelanggan

\begin{tabular}{|c|c|c|c|c|c|}
\hline \multicolumn{7}{|c|}{ PELAYANAN 3 } \\
\hline \multicolumn{2}{|c|}{} & Frequency & Percent & Valid Percent & $\begin{array}{c}\text { Cumulative } \\
\text { Percent }\end{array}$ \\
\hline \multirow{4}{*}{ Valid } & 3 & 3 & 10,0 & 10,0 & 10,0 \\
\cline { 2 - 6 } & 4 & 15 & 50,0 & 50,0 & 60,0 \\
\cline { 2 - 6 } & 5 & 12 & 40,0 & 40,0 & 100,0 \\
\cline { 2 - 6 } & Total & 30 & 100,0 & 100,0 & \\
\hline
\end{tabular}

Dengan pertanyaan nomor 3 ini, bila nilai jawabannya dijumlahkan yaitu $(12 \times 5)+(15 \times 4)$ + (3 x 3) maka akan diperoleh nilai sebesar 126 Angka tersebut bila dibagi dengan jumlah responden sebanyak 30 orang akan menghasilkan nilai 126: $30=4,2$ Kemudian bila dibandingkan dengan kriteria penilaian, maka 4,2 termasuk kedalam kriteria sangat baik.

4. Cepat dan tanggap dalam memberikan pelayanan dapat memberi kepuasan pelanggan

\begin{tabular}{|c|c|c|c|c|c|}
\hline \multicolumn{7}{|c|}{ PELAYANAN 4 } \\
\hline \multirow{2}{*}{} & \multirow{2}{*}{ Frequency } & Percent & Valid Percent & $\begin{array}{c}\text { Cumulative } \\
\text { Percent }\end{array}$ \\
\hline \multirow{4}{*}{ Valid } & 3 & 8 & 26,7 & 26,7 & 26,7 \\
\cline { 2 - 6 } & 4 & 15 & 50,0 & 50,0 & 76,7 \\
\cline { 2 - 6 } & 5 & 7 & 23,3 & 23,3 & 100,0 \\
\cline { 2 - 6 } & Total & 30 & 100,0 & 100,0 & \\
\hline
\end{tabular}

Dengan pertanyaan nomor 4 ini, bila nilai jawabannya dijumlahkan yaitu $(7 \times 5)+(15 \times 4)$ + (8 x 3) maka akan diperoleh nilai sebesar 119 Angka tersebut bila dibagi dengan jumlah responden sebanyak 30 orang akan menghasilkan nilai 119: $30=3,96$ Kemudian bila dibandingkan dengan kriteria penilaian, maka 3,96 termasuk kedalam kriteria baik. 
5. Membangun interaksi yang baik dengan pelanggan dalam suatu pelayanan akan menimbulkan kepuasan terhadap pelanggan

\begin{tabular}{|c|c|c|c|c|c|}
\hline \multicolumn{7}{|c|}{ PELAYANAN 5 } \\
\hline \multirow{2}{*}{} & Frequency & Percent & Valid Percent & $\begin{array}{c}\text { Cumulative } \\
\text { Percent }\end{array}$ \\
\hline \multirow{4}{*}{ Valid } & 2 & 1 & 3,3 & 3,3 & 3,3 \\
\cline { 2 - 6 } & 3 & 10 & 33,3 & 33,3 & 36,7 \\
\cline { 2 - 6 } & 4 & 10 & 33,3 & 33,3 & 70,0 \\
\cline { 2 - 6 } & 5 & 9 & 30,0 & 30,0 & 100,0 \\
\cline { 2 - 6 } & Total & 30 & 100,0 & 100,0 & \\
\hline
\end{tabular}

Dengan pertanyaan nomor 5 ini, bila nilai jawabannya dijumlahkan yaitu $(9 \times 5)+(10 \times 4)$ $+(10 \times 3)+(1 \times 2)$ maka akan diperoleh nilai sebesar 117 Angka tersebut bila dibagi dengan jumlah responden sebanyak 30 orang akan menghasilkan nilai 117: $30=3,9$ Kemudian bila dibandingkan dengan kriteria penilaian, maka 3,9 termasuk kedalam kriteria baik.

6. Pemberian pelayanan yang dimaksudkan untuk memecahkan permasalahan pelanggan akan terciptanya kepuasan bagi pelanggan tersebut

\begin{tabular}{|c|c|c|c|c|c|}
\hline \multicolumn{6}{|c|}{ PELAYANAN 6} \\
\hline & & Frequency & Percent & Valid Percent & $\begin{array}{c}\text { Cumulative } \\
\text { Percent }\end{array}$ \\
\hline \multirow{5}{*}{ Valid } & 2 & 1 & 3,3 & 3,3 & 3,3 \\
\hline & 3 & 10 & 33,3 & 33,3 & 36,7 \\
\hline & 4 & 17 & 56,7 & 56,7 & 93,3 \\
\hline & 5 & 2 & 6,7 & 6,7 & 100,0 \\
\hline & Total & 30 & 100,0 & 100,0 & \\
\hline
\end{tabular}

Dengan pertanyaan nomor 6 ini, bila nilai jawabannya dijumlahkan yaitu $(2 \times 5)+(17 \mathrm{x} 4)$ $+(10 \times 3)+(1 \times 2)$ maka akan diperoleh nilai sebesar 110. Angka tersebut bila dibagi dengan jumlah responden sebanyak 30 orang akan menghasilkan nilai 110: $30=3,68$. Kemudian bila dibandingkan dengan kriteria penilaian, maka 3,68 termasuk kedalam kriteria baik. 
Jurnal Muttaqien, Vol. 2. No. 2 Juli 2021, 155-175

7. Menghasilkan karakteristik produk yang diinginkan pelanggan membuat pelanggan merasa puas

\begin{tabular}{|c|c|c|c|c|c|}
\hline \multicolumn{7}{|c|}{ PELAYANAN 7 } \\
\hline \multicolumn{2}{|c|}{} & Frequency & Percent & Valid Percent & $\begin{array}{c}\text { Cumulative } \\
\text { Percent }\end{array}$ \\
\hline \multirow{4}{*}{ Valid } & 2 & 2 & 6,7 & 6,7 & 6,7 \\
\cline { 2 - 6 } & 3 & 9 & 30,0 & 30,0 & 36,7 \\
\cline { 2 - 6 } & 4 & 9 & 30,0 & 30,0 & 66,7 \\
\cline { 2 - 6 } & 5 & 10 & 33,3 & 33,3 & 100,0 \\
\cline { 2 - 6 } & Total & 30 & 100,0 & 100,0 & \\
\hline
\end{tabular}

Dengan pertanyaan nomor 7 ini, bila nilai jawabannya dijumlahkan yaitu $(10 \times 5)+(9 x$ $4)+(8 \times 4)+(2 \times 2)$ maka akan diperoleh nilai sebesar 122. Angka tersebut bila dibagi dengan jumlah responden sebanyak 30 orang akan menghasilkan nilai 122: $30=4,07$. Kemudian bila dibandingkan dengan kriteria penilaian, maka 4,07 termasuk kedalam kriteria sangat baik. Menciptakan lingkungan yang baik dapat menimbulkan kepuasan

\begin{tabular}{|c|c|c|c|c|c|}
\hline \multicolumn{7}{|c|}{ PELAYANAN 8 } \\
\hline \multicolumn{2}{|c|}{} & Frequency & Percent & Valid Percent & $\begin{array}{c}\text { Cumulative } \\
\text { Percent }\end{array}$ \\
\hline \multirow{4}{*}{ Valid } & 2 & 8 & 26,7 & 26,7 & 26,7 \\
\cline { 2 - 6 } & 3 & 12 & 40,0 & 40,0 & 66,7 \\
\cline { 2 - 6 } & 4 & 7 & 23,3 & 23,3 & 90,0 \\
\cline { 2 - 6 } & 5 & 3 & 10,0 & 10,0 & 100,0 \\
\cline { 2 - 6 } & Total & 30 & 100,0 & 100,0 & \\
\hline
\end{tabular}

Dengan pertanyaan nomor 8 ini, bila nilai jawabannya dijumlahkan yaitu $(3 \times 5)+(7 \times 4)+$ $(12 \times 3)+(8 \times 2)$ maka akan diperoleh nilai sebesar 95. Angka tersebut bila dibagi dengan jumlah responden sebanyak 30 orang akan menghasilkan nilai 95: $30=3,17$ Kemudian bila dibandingkan dengan kriteria penilaian, maka 3,17 termasuk kedalam kriteria baik.

8. Fasilitas dan hiburan yang ada membuat pelanggan terhibur dan merasa puas

\begin{tabular}{|c|c|c|c|c|c|}
\hline \multicolumn{7}{|c|}{ PELAYANAN 9 } \\
\hline \multicolumn{2}{|c|}{} & Frequency & Percent & Valid Percent & $\begin{array}{c}\text { Cumulative } \\
\text { Percent }\end{array}$ \\
\hline \multirow{4}{*}{ Valid } & 3 & 6 & 20,0 & 20,0 & 20,0 \\
\cline { 2 - 6 } & 4 & 14 & 46,7 & 46,7 & 66,7 \\
\cline { 2 - 6 } & 5 & 10 & 33,3 & 33,3 & 100,0 \\
\cline { 2 - 6 } & Total & 30 & 100,0 & 100,0 & \\
\hline
\end{tabular}


Dengan pertanyaan nomor 9 ini, bila nilai jawabannya dijumlahkan yaitu $(10 \times 5)+(15 \times 4)$ $+(5 \times 3)$ maka akan diperoleh nilai sebesar 125. Angka tersebut bila dibagi dengan jumlah responden sebanyak 30 orang akan menghasilkan nilai 125: $30=4,17$ Kemudian bila dibandingkan dengan kriteria penilaian, maka 4,17 termasuk kedalam kriteria sangat baik.

9. Penuh perhatian dan kesabaran dalam melayani membuat pelanggan merasa puas

\begin{tabular}{|c|c|c|c|c|c|}
\hline \multicolumn{6}{|c|}{ PELAYANAN 10} \\
\hline & & Frequency & Percent & Valid Percent & $\begin{array}{c}\text { Cumulative } \\
\text { Percent }\end{array}$ \\
\hline \multirow{4}{*}{ Valid } & 3 & 3 & 10,0 & 10,0 & 10,0 \\
\hline & 4 & 16 & 53,3 & 53,3 & 63,3 \\
\hline & 5 & 11 & 36,7 & 36,7 & 100,0 \\
\hline & Total & 30 & 100,0 & 100,0 & \\
\hline
\end{tabular}

Dengan pertanyaan nomor 10 ini, bila nilai jawabannya dijumlahkan yaitu $(11 \times 5)+(16 \times$ 4) $+(3 \times 3)$ maka akan diperoleh nilai sebesar 128. Angka tersebut bila dibagi dengan jumlah responden sebanyak 30 orang akan menghasilkan nilai 128: $30=4,27$. Kemudian bila dibandingkan dengan kriteria penilaian, maka 4,27 termasuk kedalam kriteria sangat baik.

\section{Tabulasi Jawaban Variabel Kepuasan (Y) dengan skla Liker}

1. Kepuasan sebagai tingkat perasaan seseorang setelah membandingkan kinerja atau hasil yang dirasakannya dengan harapannya

\begin{tabular}{|c|c|c|c|c|c|}
\hline \multicolumn{6}{|c|}{ KEPUASAN 1 } \\
\hline \multirow{2}{*}{} & Frequency & Percent & Valid Percent & $\begin{array}{c}\text { Cumulative } \\
\text { Percent }\end{array}$ \\
\hline \multirow{4}{*}{ Valid } & 3 & 4 & 13,3 & 13,3 & 13,3 \\
\cline { 2 - 6 } & 4 & 11 & 36,7 & 36,7 & 50,0 \\
\cline { 2 - 6 } & 5 & 15 & 50,0 & 50,0 & 100,0 \\
\cline { 2 - 6 } & Total & 30 & 100,0 & 100,0 & \\
\hline
\end{tabular}

Dengan pertanyaan nomor 1 ini, bila nilai jawabannya dijumlahkan yaitu $(15 \times 5)+(11 \times 4)$ + (4 x 3) maka akan diperoleh nilai sebesar 111. Angka tersebut bila dibagi dengan jumlah responden sebanyak 30 orang akan menghasilkan nilai 131: $30=4,37$ Kemudian bila dibandingkan dengan kriteria penilaian, maka 4,37 termasuk kedalam kriteria baik. 
Jurnal Muttaqien, Vol. 2. No. 2 Juli 2021, 155-175

2. Kepuasan atau ketidakpuasan adalah interaksi antara harapan dan pengalaman sesudah memakai jasa atau pelayanan yang diberikan

\begin{tabular}{|c|c|c|c|c|c|}
\hline \multicolumn{7}{|c|}{ KEPUASAN 2 } \\
\hline \multicolumn{2}{|c|}{} & Frequency & Percent & Valid Percent & $\begin{array}{c}\text { Cumulative } \\
\text { Percent }\end{array}$ \\
\hline \multirow{4}{*}{ Valid } & 3 & 1 & 3,3 & 3,3 & 3,3 \\
\cline { 2 - 6 } & 4 & 11 & 36,7 & 36,7 & 40,0 \\
\cline { 2 - 6 } & 5 & 18 & 60,0 & 60,0 & 100,0 \\
\cline { 2 - 6 } & Total & 30 & 100,0 & 100,0 & \\
\hline
\end{tabular}

Dengan pertanyaan nomor 2 ini, bila nilai jawabannya dijumlahkan yaitu (18 x 5) + (11 x 4) + (1 x 3) maka akan diperoleh nilai sebesar 137. Angka tersebut bila dibagi dengan jumlah responden sebanyak 30 orang akan menghasilkan nilai 137: $30=4,57$ Kemudian bila dibandingkan dengan kriteria penilaian, maka 4,57 termasuk kedalam kriteria sangat baik.

3. kinerja produk lebih rendah ketimbang harapan, maka pelanggan merasa puas

\begin{tabular}{|c|c|c|c|c|c|}
\hline \multicolumn{7}{|c|}{ KEPUASAN 3 } \\
\hline \multirow{2}{*}{} & Frequency & Percent & Valid Percent & $\begin{array}{c}\text { Cumulative } \\
\text { Percent }\end{array}$ \\
\hline \multirow{4}{*}{ Valid } & 3 & 2 & 6,7 & 6,7 & 6,7 \\
\cline { 2 - 6 } & 4 & 10 & 33,3 & 33,3 & 40,0 \\
\cline { 2 - 6 } & 5 & 18 & 60,0 & 60,0 & 100,0 \\
\cline { 2 - 6 } & Total & 30 & 100,0 & 100,0 & \\
\hline
\end{tabular}

Dengan pertanyaan nomor 3 ini, bila nilai jawabannya dijumlahkan yaitu $(18 \times 5)+(10 x 4)$ $+(2 \times 3)$ maka akan diperoleh nilai sebesar 136. Angka tersebut bila dibagi dengan jumlah responden sebanyak 30 orang akan menghasilkan nilai 136: $30=4,46$ Kemudian bila dibandingkan dengan kriteria penilaian, maka 4,46 termasuk kedalam kriteria sangat baik.

4. Kepuasan merupakan penilaian mengenai ciri atau keistimewaan produk atau jasa, atau produk itu sendiri

\begin{tabular}{|c|c|c|c|c|c|}
\hline \multicolumn{6}{|c|}{ KEPUASAN 4 } \\
\hline \multicolumn{2}{|c|}{} & Frequency & Percent & Valid Percent & $\begin{array}{c}\text { Cumulative } \\
\text { Percent }\end{array}$ \\
\hline \multirow{3}{*}{ Valid } & 4 & 11 & 36,7 & 36,7 & 36,7 \\
\cline { 2 - 6 } & 5 & 19 & 63,3 & 63,3 & 100,0 \\
\cline { 2 - 6 } & Total & 30 & 100,0 & 100,0 & \\
\hline
\end{tabular}


Dengan pertanyaan nomor 4 ini, bila nilai jawabannya dijumlahkan yaitu $(19 \times 5)+(11 \times 4)$ maka akan diperoleh nilai sebesar 139. Angka tersebut bila dibagi dengan jumlah responden sebanyak 30 orang akan menghasilkan nilai 139: $30=4,63$ Kemudian bila dibandingkan dengan kriteria penilaian, maka 4,63 termasuk kedalam kriteria sangat baik.

5. Kepuasan pelanggan adalah perasaan pelanggan terhadap satu jenis pelayanan yang didapatkannya

\begin{tabular}{|c|c|c|c|c|c|}
\hline \multicolumn{7}{|c|}{ KEPUASAN 5 } \\
\hline \multirow{2}{*}{} & \multirow{2}{*}{ Frequency } & Percent & Valid Percent & $\begin{array}{c}\text { Cumulative } \\
\text { Percent }\end{array}$ \\
\hline \multirow{4}{*}{ Valid } & 3 & 8 & 26,7 & 26,7 & 26,7 \\
\cline { 2 - 6 } & 4 & 10 & 33,3 & 33,3 & 60,0 \\
\cline { 2 - 6 } & 5 & 12 & 40,0 & 40,0 & 100,0 \\
\cline { 2 - 6 } & Total & 30 & 100,0 & 100,0 & \\
\hline
\end{tabular}

Dengan pertanyaan nomor 5 ini, bila nilai jawabannya dijumlahkan yaitu $(8 \times 5)+(10 \times 4)$ $+(12 \times 3)$ maka akan diperoleh nilai sebesar 116. Angka tersebut bila dibagi dengan jumlah responden sebanyak 30 orang akan menghasilkan nilai 116: $30=3,87$ Kemudian bila dibandingkan dengan kriteria penilaian, maka 3,87 termasuk kedalam kriteria baik.

6. Kepuasan pelanggan adalah perasaan senang atau kecewa seseorang yang muncul setelah membandingkan kinerja (hasil) produk yang dipikirkan terhadap kinerja yang diharapkan

\begin{tabular}{|c|c|c|c|c|c|}
\hline \multicolumn{7}{|c|}{ KEPUASAN 6 } \\
\hline \multicolumn{2}{|c|}{} & Frequency & Percent & Valid Percent & $\begin{array}{c}\text { Cumulative } \\
\text { Percent }\end{array}$ \\
\hline \multirow{4}{*}{ Valid } & 2 & 2 & 6,7 & 6,7 & 6,7 \\
\cline { 2 - 6 } & 3 & 8 & 26,7 & 26,7 & 33,3 \\
\cline { 2 - 6 } & 4 & 10 & 33,3 & 33,3 & 66,7 \\
\cline { 2 - 6 } & 5 & 10 & 33,3 & 33,3 & 100,0 \\
\cline { 2 - 6 } & Total & 30 & 100,0 & 100,0 & \\
\hline
\end{tabular}

Dengan pertanyaan nomor 6 ini, bila nilai jawabannya dijumlahkan yaitu $(10 \times 5)+(10 \times 4)$ $+(8 \times 3)+(2 \times 2)$ maka akan diperoleh nilai sebesar 118. Angka tersebut bila dibagi dengan jumlah responden sebanyak 30 orang akan menghasilkan nilai 118: $30=3,93$.

Kemudian bila dibandingkan dengan kriteria penilaian, maka 3,93 termasuk kedalam kriteria baik. 
Jurnal Muttaqien, Vol. 2. No. 2 Juli 2021, 155-175

7. Kepuasan konsumen adalah menyediakan tingkat kesenangan konsumen berkaitan dengan pemenuhan kebutuhan konsumsi pelanggan

\begin{tabular}{|c|c|c|c|c|c|}
\hline \multicolumn{7}{|c|}{ KEPUASAN 7 } \\
\hline \multirow{2}{*}{} & Frequency & Percent & Valid Percent & $\begin{array}{c}\text { Cumulative } \\
\text { Percent }\end{array}$ \\
\hline \multirow{4}{*}{ Valid } & 2 & 1 & 3,3 & 3,3 & 3,3 \\
\cline { 2 - 6 } & 3 & 9 & 30,0 & 30,0 & 33,3 \\
\cline { 2 - 6 } & 4 & 9 & 30,0 & 30,0 & 63,3 \\
\cline { 2 - 6 } & 5 & 11 & 36,7 & 36,7 & 100,0 \\
\cline { 2 - 6 } & Total & 30 & 100,0 & 100,0 & \\
\hline
\end{tabular}

Dengan pertanyaan nomor 7 ini, bila nilai jawabannya dijumlahkan yaitu $(11 \times 5)+(9 \times 4)$ $+(9 \times 3)+(1 \times 2)$ maka akan diperoleh nilai sebesar 120. Angka tersebut bila dibagi dengan jumlah responden sebanyak 30 orang akan menghasilkan nilai 120: $30=4$

Kemudian bila dibandingkan dengan kriteria penilaian, maka 4 termasuk kedalam kriteria baik.

8. Kenyamanan merupakan faktor pendorong terciptanya kepuasan pelanggan

\begin{tabular}{|c|c|c|c|c|c|}
\hline \multicolumn{7}{|c|}{ KEPUASAN 8 } \\
\hline \multirow{2}{*}{} & Frequency & Percent & Valid Percent & $\begin{array}{c}\text { Cumulative } \\
\text { Percent }\end{array}$ \\
\hline \multirow{4}{*}{ Valid } & 2 & 1 & 3,3 & 3,3 & 3,3 \\
\cline { 2 - 6 } & 3 & 10 & 33,3 & 33,3 & 36,7 \\
\cline { 2 - 6 } & 4 & 11 & 36,7 & 36,7 & 73,3 \\
\cline { 2 - 6 } & 5 & 8 & 26,7 & 26,7 & 100,0 \\
\cline { 2 - 6 } & Total & 30 & 100,0 & 100,0 & \\
\hline
\end{tabular}

Dengan pertanyaan nomor 8 ini, bila nilai jawabannya dijumlahkan yaitu $(8 \times 5)+(11 \times 4)$ $+(10 \times 3)+(1 \times 2)$ maka akan diperoleh nilai sebesar 116. Angka tersebut bila dibagi dengan jumlah responden sebanyak 30 orang akan menghasilkan nilai 116: $30=3,87$.

Kemudian bila dibandingkan dengan kriteria penilaian, maka 3,87 termasuk kedalam kriteria baik. 
9. Harga murah adalah sumber kepuasan yang penting bagi pelanggan

\begin{tabular}{|c|c|c|c|c|c|}
\hline \multicolumn{6}{|c|}{ KEPUASAN 9} \\
\hline & & Frequency & Percent & Valid Percent & $\begin{array}{c}\text { Cumulative } \\
\text { Percent }\end{array}$ \\
\hline \multirow{5}{*}{ Valid } & 2 & 1 & 3,3 & 3,3 & 3,3 \\
\hline & 3 & 9 & 30,0 & 30,0 & 33,3 \\
\hline & 4 & 12 & 40,0 & 40,0 & 73,3 \\
\hline & 5 & 8 & 26,7 & 26,7 & 100,0 \\
\hline & Total & 30 & 100,0 & 100,0 & \\
\hline
\end{tabular}

Dengan pertanyaan nomor 9 ini, bila nilai jawabannya dijumlahkan yaitu $(8 \times 5)+(12 \times 4)$ $+(9 \times 3)+(1 \times 2)$ maka akan diperoleh nilai sebesar 117. Angka tersebut bila dibagi dengan jumlah responden sebanyak 30 orang akan menghasilkan nilai 117: $30=3,9$ Kemudian bila dibandingkan dengan kriteria penilaian, maka 3,9 termasuk kedalam kriteria baik.

10. Pelanggan akan merasa puas bahwa produk yang mereka gunakan berkualitas

\begin{tabular}{|c|c|c|c|c|c|}
\hline \multicolumn{7}{|c|}{ KEPUASAN 10 } \\
\hline \multicolumn{2}{|c|}{} & Frequency & Percent & Valid Percent & $\begin{array}{c}\text { Cumulative } \\
\text { Percent }\end{array}$ \\
\hline \multirow{2}{*}{ Valid } & 3 & 3 & 10,0 & 10,0 & 10,0 \\
\cline { 2 - 6 } & 4 & 7 & 23,3 & 23,3 & 33,3 \\
\hline \multirow{3}{*}{} & 5 & 20 & 66,7 & 66,7 & 100,0 \\
\cline { 2 - 6 } & Total & 30 & 100,0 & 100,0 & \\
\hline
\end{tabular}

Dengan pertanyaan nomor 10 ini, bila nilai jawabannya dijumlahkan yaitu $(20 \times 5)+(7 \times 4)$ $+(3 \times 3)$ maka akan diperoleh nilai sebesar 137. Angka tersebut bila dibagi dengan jumlah responden sebanyak 30 orang akan menghasilkan nilai 137: $30=4,57$ Kemudian bila dibandingkan dengan kriteria penilaian, maka 3,63 termasuk kedalam kriteria sangat baik.

\section{Uji Validitas}

Hasil uji validitas melalui program SPSS 23 dengan membandingkan nilai Pearson Correlation (korelasi product moment) dengan nilai rtabel dengan menggunakan tingkat keyakinan $95 \%, \alpha=5 \%$, df1 3-1 = 2 (jumlah variabel bebas dan terikat dikurangkan 1), dan df2 (n-2) atau $32-2=30$ (n adalah jumlah sampel). Untuk lebih jelasnya, hasil uji validitas dapat dilihat pada tabel berikut: 
Jurnal Muttaqien, Vol. 2. No. 2 Juli 2021, 155-175

Hasil Uji Validitas

\begin{tabular}{|c|c|c|c|c|}
\hline \multicolumn{4}{|c|}{ Descriptive Statistics } & \multirow{2}{*}{ Keterangan } \\
\hline & Mean & Std. Deviation & $\mathrm{N}$ & \\
\hline PELAYANAN 1 & 4,33 &, 711 & 30 & Valid \\
\hline PELAYANAN 2 & 4,27 & 828 & 30 & Valid \\
\hline PELAYANAN 3 & 4,30 & ,651 & 30 & Valid \\
\hline PELAYANAN 4 & 3,97 & ,718 & 30 & Valid \\
\hline PELAYANAN 5 & 3,90 & 885 & 30 & Valid \\
\hline PELAYANAN 6 & 3,67 & ,661 & 30 & Valid \\
\hline PELAYANAN 7 & 3,90 & 960 & 30 & Valid \\
\hline PELAYANAN 8 & 3,17 & 950 & 30 & Valid \\
\hline PELAYANAN 9 & 4,13 &, 730 & 30 & Valid \\
\hline PELAYANAN 10 & 4,27 & ,640 & 30 & Valid \\
\hline KEPUASAN 1 & 4,37 &, 718 & 30 & Valid \\
\hline KEPUASAN 2 & 4,57 &, 568 & 30 & Valid \\
\hline KEPUASAN 3 & 4,53 & ,629 & 30 & Valid \\
\hline KEPUASAN 4 & 4,63 &, 490 & 30 & Valid \\
\hline KEPUASAN 5 & 4,13 & 819 & 30 & Valid \\
\hline KEPUASAN 6 & 3,93 & ,944 & 30 & Valid \\
\hline KEPUASAN 7 & 4,00 & ,910 & 30 & Valid \\
\hline KEPUASAN 8 & 3,87 & 860 & 30 & Valid \\
\hline KEPUASAN 9 & 3,90 & 845 & 30 & Valid \\
\hline KEPUASAN 10 & 4,57 & ,679 & 30 & Valid \\
\hline
\end{tabular}

Berdasarkan tabel hasil uji validitas di atas, diketahui bahwa seluruh item pertanyaan yang digunakan dalam penelitian ini adalah valid, yang ditunjukkan dengan nilai dari masingmasing item pertanyaan memiliki nilai Pearson Correlation positif dan lebih besar dari pada nilai rtabel.

\section{Uji Reabilitas}

Teknik yang digunakan untuk mengukur tingkat reliabilitas adalah Cronbach Alpha dengan cara membandingkan nilai Alpha dengan standarnya, dengan ketentuan jika:

1. Nilai Cronbach Alpha 0,00 s.d. 0,20, berarti kurang reliabel

2. Nilai Cronbach $A \not h h a>0,20$ s.d. 0,40, berarti agak reliabel

3. Nilai Cronbach $A \not p h a>0,40$ s.d. 0,60, berarti cukup reliabel

4. Nilai Cronbach Alpha $>0,60$ s.d. 0,80, berarti reliabel

5. Nilai Cronbach $A \not p h a>0,80$ s.d. 1,00, berarti sangat reliable

Tabel di bawah ini menunjukkan hasil pengujian reliabilitas dengan menggunakan alat bantu SPSS 23, dalam tabel diatas menjelaskan dengan menggunakan nilai Cronbach Alpha 
dimana dalam nilai-nilai tersebut terdapat skala yang dapat mempermudah untuk menetukan tingkatan dalam nilai reliabilitas tersebut.

Hasil Uji Reliabilitas

\begin{tabular}{|c|c|}
\hline \multicolumn{2}{|c|}{ Reliability Statistics } \\
\hline Cronbach's Alpha $^{\mathrm{a}}$ & N of Items \\
\hline 0,823 & 20 \\
\hline
\end{tabular}

Berdasarkan hasil uji reliabilitas, dua puluh dua item variable (pertanyaan) memiliki koefisien alpha lebih besar dari 0,80. Berdasarkan ketentuan di atas maka variabel-variabel dalam penelitian ini sangat reliable.

\section{Analisa Regresi}

\section{Hasil Uji Korelasi}

\begin{tabular}{|c|c|c|c|c|}
\hline \multicolumn{5}{|c|}{ Model Summary } \\
\hline Model & $\mathrm{R}$ & R Square & $\begin{array}{c}\text { Adjusted R } \\
\text { Square }\end{array}$ & $\begin{array}{c}\text { Std. Error of } \\
\text { the Estimate }\end{array}$ \\
\hline 1 & $0,510^{\mathrm{a}}$ &, 2601 &, 440 & 1,8816 \\
\hline
\end{tabular}

a. Predictors: (Constant), X1, PELAYANAN

ANGKRINGAN

Hasil uji diatas menjelaskan besarnya nilai korelasi atau hubungan $(R)$ yaitu sebesar 0,510 dan dijelaskan besarnya prosentase pengaruh variabel bebas terhadap variabel terikat yang disebut koefisien determinasi (R2) sebesar 0,2601, yang mengantung pengertian bahwa pengaruh variabel bebas (Pelayanan) terhadap variabel terikat (Kepuasan) adalah sebesar $26,01 \%$, sedangkan sisa nya di pengaruhi oleh variabel yang lain.

\section{Hasil Uji Anova}

\begin{tabular}{|c|c|c|c|c|c|c|}
\hline \multicolumn{7}{|c|}{ ANOVA $^{\mathbf{a}}$} \\
\hline \multirow{2}{*}{ Model } & $\begin{array}{c}\text { Sum of } \\
\text { Squares }\end{array}$ & Df & $\begin{array}{c}\text { Mean } \\
\text { Square }\end{array}$ & F & Sig. \\
\hline \multirow{3}{*}{1} & Regression & 63,634 & 2 & 46,319 & 13,040 &, $000^{\mathrm{b}}$ \\
\cline { 2 - 7 } & Residual & 102,031 & 27 & 3,927 & & \\
\cline { 2 - 8 } & Total & 195,667 & 29 & & & \\
\hline
\end{tabular}

a. Dependent Variable: KEPUASAN PELANGGAN

b. Predictors: (Constant), X1, PELAYANAN

ANGKRINGAN

Dari output tersebut terlihat bahwa $\mathrm{F}$ hitung $=13,040$ dengan tingkat signifikansi atau probabilitas $0,000<0,05$, maka model regresi dapat dipakai untuk memprediksi variabel pelayanan. 
Hasil Uji Persamaan Regresi

\begin{tabular}{|c|c|c|c|c|c|c|}
\hline \multicolumn{7}{|c|}{ Coefficients $^{\mathrm{a}}$} \\
\hline & \multirow[t]{2}{*}{ Model } & \multicolumn{2}{|c|}{$\begin{array}{c}\text { Unstandardized } \\
\text { Coefficients }\end{array}$} & \multirow{2}{*}{$\begin{array}{c}\begin{array}{c}\text { Standardized } \\
\text { Coefficients }\end{array} \\
\text { Beta } \\
\end{array}$} & \multirow[t]{2}{*}{$\mathrm{t}$} & \multirow[t]{2}{*}{ Sig. } \\
\hline & & $\mathrm{B}$ & Std. Error & & & \\
\hline \multirow{3}{*}{1} & (Constant) & 31,16 & 4,079 & & ,649 & ,834 \\
\hline & $\begin{array}{c}\text { PELAYANAN } \\
\text { ANGKRINGAN }\end{array}$ & 7,50 & ,323 & ,061 & $\begin{array}{c}4,21 \\
2\end{array}$ & ,003 \\
\hline & $\mathrm{X} 1$ & ,106 & ,374 & ,082 & $\begin{array}{c}5,28 \\
3\end{array}$ & ,038 \\
\hline
\end{tabular}

Pada tabel coeficients, pada kolom B pada constant (a) adalah 31,16, sedangkan nilai pelayanan (b) adalah 7,50, sehingga persamaan regresinya dapat ditulis:

$\mathrm{Y}=\mathrm{a}+\mathrm{bX}$ atau $\mathrm{Y}=31,16+$
$7,50 \mathrm{X}$

Koefisien dinamakan koefisien arah regresi dan menyatakan perubahan rata-rata variabel Y untuk setiap perubahan variabel $\mathrm{X}$ sebesar satu satuan. Perubahan nini merupakan pertabahan bila b bertanda positif dan persamaan tersebut dapat diterjemahkan:

1. Konstanta sebesar 31,16 menyatakan bahwa jika tidak ada nilai pelayanan maka nilai kepuasan sebesar 31,16.

2. Koefisien regresi $X$ sebesar 7,50 menyatakan bahwa setiap penambahan 1 nilai pelayanan, maka nilai kepuasan bertambah sebesar 7,50.

\section{F. PEMBAHASAN}

1. $\mathrm{R}=0,510$

Dengan didapatkan korelasi sebesar 0,510, berdasarkan tabel hasil uji korelasi maka pengaruh pelayanan terhadap kepuasan pelanggan adalah sedang.

2. $\mathrm{R}^{2}=26,01 \%$

Dengan koefisien determinasi ini menunjukan bahwa kontribusi pelayanan terhadap kepuasan pelanggan sebesar 26,01\% sedangkan sisanya 73,99\% dipengaruhi oleh faktor lain.

3. Dengan didapat persamaan regresi linier $\mathrm{Y}=31,16+7,5 \mathrm{X}$

Artinya, jika nilai X bertambah maka nilai $\mathrm{Y}$ juga akan semakin besar. 
Maka dapat dikatakan antara variabel X (Pelayanan) dan variabel Y (Kepuasan) tidak terdapat pengaruh yang kuat. Jadi pelayanan tidak beerpengaruh terhadap kepuasan.

4. Uji Hipotesist

Untuk mengetahui apakah korelasi yang diperoleh signifikan atau tidak, maka akan dilakukan pengujian dengan menggunakan analisis uji " $t$ ". Apabila t-Hitung lebih besar dari t-Tabel, maka Ho ditolak dan Ha diterima. Hal tersebut berarti terdapat hubungan antara pelayanan dengan kepuasan.

Hasil analisis uji t diperoleh nilai t-hitung sebesar 7,649 sedangkan t-tabel sebesar 2,048 untuk mengambil keputusan dari pengujian hipotesa tersebut diatas digunakan uji dua arah dengan tingkat nyata $(\alpha)$ sebesar 5\% dengan tingkat kepercayaan/keyakinan (signifikan level) sebesar 95\% dengan derajat kebebasan (dk) n-2. Karena yang dilakukan uji dua arah maka digunakan $t \alpha / 2$ atau dengan $\alpha / 2$ yaitu 0,05 dibagi dua sebesar 0,025 .

Dari hasil tersebut diatas dapat dilihat bahwa thitung $>$ t-tabel yaitu 7,649 $>$ 2,048 maka Ho ditolak, Ha diterima. Hal ini menunjukan bahwa koefisien korelasi antara pelayanan (variabel X) terhadap kepuasan (variabel Y) terdapat hubungan yang positif antara pelayanan terhadap kepuasan pelanggan Angkringan Aba Agus.

\section{G. Penutup}

\section{Kesimpulan}

Kepuasan pelanggan berpengaruh positif dan signifikan berarti kedua variabel dalam penelitian ini tidak adanya variabel yang lebih dominan sehingga dinyatakan tidak terbukti dan tidak dapat diterima. Berdasarkan temuan tersebut maka Angkringan Abah Agus karawang disarankan meningkatkan pelayanannya.

\section{Saran}

Perlunya peningkatan mutu pelayanan yang diberikan sebagai rangsangan untuk meningkatkan kepuasan pelanggan angkringan dan untuk mendapatkan kepuasan pelanggan yang diharapkan juga Perlu adanya proses penilaian yang berkala atas pelayanan yang diberikan sebagai tolak ukur kepuasan yang tepat bagi pelanggan. 
Jurnal Muttaqien, Vol. 2. No. 2 Juli 2021, $155-175$

\section{Daftar Pustaka}

Gaspersz, Vincent, 2003. Manajemen Bisnis Total-Total Quality Management.Penerbit PT. Gramedia Pustaka Utama, Jakarta.

Irawan, Handi. 10 Prinsip Kepuasan Pelanggan. 2002. PT Elex Media Computindo: Jakarta. Kotler dan Keller. 2012. Marketing Management. Edisi 14. Global Edition. Pearson Prentice Hall.

Kotler, Philip dan Kevin L. Keller 2009. Manajemen Pemasaran. (Terjemahan: Bob Sabran) Edisi 13 Jilid 1 dan 2. Erlangga, Jakarta.

Loina, (2001: 38), Hubungan masyarakat membina hubungan baik dengan publik.

Lupiyoadi, Hamdani. 2006. Manajemen Pemasaran Jasa, Edisi Kedua. Jakarta: Penerbit Salemba Empat, 181.

Lupiyoadi, R. 2006. Manajemen Pemasaran Jasa untuk Teori dan Praktek. Jakarta: PT. Salemba Emban Patrio.

Luthans, Fred. (2006). Perilaku Organisasi, Edisi Sepuluh. Yogyakarta: Penerbit Andi.

Moenir, 2014, Manajemen Pelayanan Umum di Indonesia, Jakarta

Napitupulu, Paimin. 2001.PelayananPublik dan Customer Satisfaction. PT. Alumni.Bandung.

Nasution. 2001. Manajemen Mutu Terpadu (Total Quality Management), Anggota IKPI, Ghalia Indonesia: Jakarta.

Oliver, Sandra. (2007). "Strategi Public Relations”. Penerbit Erlangga. Jakarta

Parasuraman, A., V. A..Zeithaml, dan L.L Berry, (1998), SERVQUAL: A Multiple - Item

Scale For Measuring Consumer Perceptions of Service quality, Journal Of retailing, Vo.64,No.1

Perangin angin, Loina (2001). Hubungan Masyarakat: Membina Hubungan Baik Dengan Publik. Bandung: CV. Lalolo.

Ratminto \& Atik, S.W. 2005.Manajemen Pelayanan: Pengembangan Model Konseptual, Penerapan Citizen's Charter dan Standar Pelayanan Minimal.Yogyakarta: Pustaka Pelajar.

Robbin, Stephen P dan Timothy A. Judge, Prilaku Organisasi, Prentice Hall, Jakarta Sinambela, Lijan Poltak. 2010. Reformasi Pelayanan Publik, Jakarta Sugiyono, 2012, Metode Penelitian Kuantitatif, Kualitatif \& RND, Alfabeta, Bandung. 
Umar, Husein. (2003). Riset Pemasaran dan Perilaku Konsumen. Gramedia Pustaka Utama, Jakarta.

V3210 (2017), Stastitical Package for the Social Sciences (SPSS) 24

Zeithaml et al. (1990). Delivering Quality Service.NewYork: The Free Press. 